\section{Dallisgrass (Paspalum dilatatum) Control with Thiencarbazone-methyl, Foramsulfuron, and Halosulfuron- methyl in Bermudagrass Turf}

\author{
Christopher R. Johnston and Gerald M. Henry ${ }^{1}$ \\ Department of Crop and Soil Sciences, University of Georgia, 3111 Miller \\ Plant Science Building, Athens, GA 30602
}

Additional index words. Cynodon dactylon, turfgrass, weed, iodosulfuron-methyl-sodium, dicamba, dormancy, phytotoxicity, perennial grass

\begin{abstract}
Dallisgrass control in response to various timings and frequencies of single and combination herbicide treatments was evaluated from 2010 to 2012 in Lubbock, TX. Treatments included thiencarbazone-methyl + foramsulfuron + halosulfuron-methyl (TFH) at $15+31+47$ or $22+45+70 \mathrm{~g}$ a.i./ha, foramsulfuron at $106 \mathrm{~g}$ a.i./ha, and foramsulfuron + thiencarbazone-methyl + iodosulfuron-methyl-sodium + dicamba (foramsulfuron + TID) at $106+(22+5+147) \mathrm{g}$ a.i./ha. Applications of TFH provided $\mathbf{5 6 5 \%}$ dallisgrass control by 10 weeks after initial treatment (WAIT) across two rates $(15+31+47$ or $22+45+70 \mathrm{~g}$ a.i./ha) and three application timings [September, October, or September followed by (fb) a sequential October application]. At 37 WAIT, sequential applications of TFH at $15+31+47 \mathrm{~g}$ a.i./ha resulted in $92 \%$ dallisgrass control. Similarly, application of TFH at $22+45+70 \mathrm{~g}$ a.i./ha provided $94 \%$ and $97 \%$ dallisgrass control when applied in September or September fb October, respectively. However, single October applications of TFH only provided $\mathbf{5 5 \%} \%$ dallisgrass control 37 WAIT. Sequential combinations of foramsulfuron + TID at $106+(22+5+147) \mathrm{g}$ a.i./ha provided $93 \%$ dallisgrass control 37 WAIT, equivalent to single applications of TFH at $15+31+47 \mathrm{~g}$ a.i./ha and sequential treatments at $15+31+47$ or $22+45+70 \mathrm{~g}$ a.i./ha. However, initial control (10 WAIT) with foramsulfuron + TID was moderate $(63 \%)$. Sequential foramsulfuron applications (106 $\mathrm{g}$ a.i./ha) resulted in inadequate dallisgrass control (35\% and $48 \%) 10$ and 37 WAIT, respectively. Results from this study suggest that long-term dallisgrass control may be achieved when TFH is applied in September or September fb October. Applications initiated in October resulted in inadequate control, regardless of rate, which may be linked to reduced herbicidal absorption and translocation due to the onset of dallisgrass dormancy in late fall. Chemical names used: methyl 4-[(4,5-dihydro-3-methoxy-4-methyl-5-oxo-1 H-1,2,4-triazol-1-yl)carbonylsulfamoyl]-5methylthiophene-3-carboxylate (thiencarbazone-methyl); 2-[(4,6-dimethoxypyrimidin2-yl)carbamoylsulfamoyl]-4-formamido- $\mathrm{N}, \mathrm{N}$-dimethylbenzamide (foramsulfuron); methyl 3-chloro-5-[(4,6-dimethoxypyrimidin-2-yl)carbamoylsulfamoyl]-1-methylpyrazole-4carboxylate (halosulfuron-methyl); sodium (5-iodo-2-methoxycarbonylphenyl)sulfonyl[(4-methoxy-6-methyl-1,3,5-triazin-2-yl)carbamoyl]azanide (iodosulfuron-methyl-sodium); and 3,6-dichloro-2-methoxybenzoic acid (dicamba).
\end{abstract}

Dallisgrass (Paspalum dilatatum Poir.) is a problematic rhizomatous perennial grass weed of managed turfgrass stands throughout the southern United States. Dallisgrass is often considered a desirable grass species in pastures and roadsides; however, its wide adaptability to different environmental conditions has likely contributed to it becoming a weed in turfgrass settings. The presence of dallisgrass reduces turfgrass aesthetics and functionality of recreational, commercial, and residential turfgrass stands (Elmore et al., 2013; Henry et al., 2007a). Tolerance of dallisgrass to low mowing heights $(1.3 \mathrm{~cm})$ has been reported, suggesting that it can be problematic in both golf course fairways and

Received for publication 4 Feb. 2016. Accepted for publication 4 Apr. 2016.

${ }^{1}$ Corresponding author. E-mail: gmhenry@uga.edu. roughs (Henry et al., 2007a). Furthermore, dallisgrass growth is often encouraged in areas with high volumetric water content and its survival has been observed in regions prone to flooding (Henry et al., 2009; Loreti and Oesterheld, 1996; Rubio et al., 1995; Rubio and Lavado, 1999).

Chemical control options are currently limited for dallisgrass. One of the most common control programs is the use of sequential monosodium methanearsonate (MSMA) applications; however, this may present phytotoxicity concerns to warmseason turfgrasses (Henry et al., 2007b; Henry et al., 2008). Summer applications of MSMA have been reported to cause reductions in turf quality in both 'Tifway' hybrid bermudagrass (Cynodon dactylon $\times$ Cynodon transvaalensis Burtt-Davy) and common bermudagrass [C. dactylon (L.) Pers.] (McCarty et al., 1991). Additionally, commercial availability and continued use of MSMA has been uncertain following the 2009 decision by the Environmental Protection Agency, which eliminated the use of MSMA on home lawns and athletic fields, while restricting use on sod farms, golf courses, and highway rights of way and prohibiting use in all turfgrass environments after 31 Dec. 2013 (United States Environmental Protection Agency (EPA), 2009). The 2009 EPA decision on MSMA prohibition was recently delayed, pending a registration review that began in 2013 and is scheduled for completion in 2019 (United States Environmental Protection Agency, 2015).

Limitations on the efficacy of other herbicides for dallisgrass control have also been reported. Henry et al. (2007b) observed $<60 \%$ dallisgrass control 1 month after initial treatment (MAIT) in response to sequential foramsulfuron applications made in summer; control was $<5 \% 1$ year after initial treatment. Bingham et al. (1993) also reported insufficient control of dallisgrass in tall fescue (Festuca arundinacea Schreb.) roadsides with fenoxaprop and imazethapyr. Herbicide application timing has also been determined to be a limiting factor for effective dallisgrass control, and previous research has illustrated the ineffectiveness of certain herbicides when applied after early spring. Brosnan et al. (2010) reported that single fluazifop applications made after the accumulation of 500 growing degree days provided $46 \%$ and $0 \%$ dallisgrass control 28 and $76 \mathrm{~d}$ after treatment, respectively, and sequential applications resulted in similar trends. The same research indicated that tank mixtures of fluazifop with mesotrione provided no better control than single or sequential fluazifop applications alone. In addition to a lack of efficacy for dallisgrass control when applied after early spring, it has also been well documented that fluazifop may cause phytotoxicity to bermudagrass turf (Bryson and Wills, 1985; Johnson, 1992; McElroy and Breeden, 2006;). Nonselectivity of glyphosate limits its use to spot spray applications that may cause nontarget damage to hybrid bermudagrass (Henry et al., 2008). The lack of noninjurious and effective herbicides for dallisgrass control warrants further investigation into chemical control options for use in warm-season turfgrasses.

A combination product containing the acetolactate synthase inhibitors TFH became commercially available in 2012 for the control of annual and perennial grass weeds, sedges, and broadleaf weeds in bermudagrass and zoysiagrass (Zoysia spp.) turf (Anonymous, 2016). Previous research examined the efficacy of this combination chemistry for the control of nutsedge (Cyperus sp.) in bermudagrass (Henry et al., 2013). May and June applications of TFH resulted in $89 \%$ to $93 \%$ yellow nutsedge (Cyperus esculentus L.) control 12 WAIT (Henry et al., 2013). Yellow nutsedge, like dallisgrass, is a difficultto-control perennial weed with abundant vegetative tissue for carbohydrate storage (Wills, 1987). Perennial grass rhizomes act 
as sink tissue for carbohydrate reserves before the onset of dormancy; therefore, coinciding herbicide treatments with basipetal carbohydrate movement may maximize longterm perennial weed control (Davis et al., 1978; Smith et al., 1993). Research investigating this approach to dallisgrass control is lacking and highly warranted. Thus, the objectives of this research were to evaluate the efficacy of fall applications of TFH compared with other herbicides on dallisgrass control in bermudagrass turf, and to determine the effect of rate, application timing, and number of applications on efficacy of these herbicide treatments.

\section{Materials and Methods}

Field experiments were conducted during the fall of 2010 at Meadowbrook Golf Course

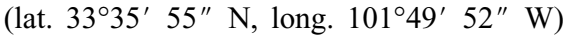
and in 2011 at Texas Tech University (lat. $33^{\circ} 35^{\prime} 4^{\prime \prime} \mathrm{N}$, long. $101^{\circ} 53^{\prime} 3^{\prime \prime} \mathrm{W}$ ) in Lubbock, TX. Research at Meadowbrook Golf Course was performed on a common bermudagrass rough maintained at a height of $5.1 \mathrm{~cm}$. Research at Texas Tech University was conducted on a 'Tifway' hybrid bermudagrass maintained at a height of $3.8 \mathrm{~cm}$. Both sites contained mature dallisgrass infestations that had been present for multiple years. The Meadowbrook Golf Course and Texas Tech University site soils were both brownfield sandy clay loams (loamy, mixed, super active, thermic Arenic Aridic Paleustalfs), with a $\mathrm{pH}$ of 7.9 and organic matter content of $1.1 \%$ and a $\mathrm{pH}$ of 8.1 and organic matter content of $1.4 \%$, respectively. Plots measured $1.5 \times 1.5 \mathrm{~m}$ and were arranged in a randomized complete block design with four replications at each location. Percent cover of dallisgrass was assessed before initial herbicide applications for each site. Initial dallisgrass cover ranged from $50 \%$ to $95 \%$ and was used to estimate control. Both sites were irrigated daily with an automated system, with the exception of the first $24 \mathrm{~h}$ following herbicide applications.

Nine herbicide treatments and a nontreated control were included in both experiments and are listed in Table 1. Initial herbicide treatments were made on 27 Sept. 2010 and 23 Sept. 2011 at Meadowbrook Golf Course and Texas Tech University, respectively. Herbicides applied included TFH (Tribute Total; Bayer Environmental Science, Research Triangle Park, NC) at $15+31+47$ or $22+45+$ $70 \mathrm{~g}$ a.i./ha, foramsulfuron (Revolver 0.19 SC; Bayer Environmental Science, Research Triangle Park, NC) at $106 \mathrm{~g}$ a.i./ha, and TID (Celsius WG; Bayer Environmental Science, ) at $22+5+147 \mathrm{~g}$ a.i./ha. All TFH treatments included methylated seed oil (Dyne-Amic; Helena Chemical Company, Collierville, $\mathrm{TN}$ ) and ammonium sulfate (Sigma-Aldrich, St. Louis, MO) at $0.5 \% \mathrm{v} / \mathrm{v}$ and $2 \% \mathrm{w} / \mathrm{v}$, respectively. October and sequential treatments were applied on 21 Oct. 2010 and 2011 at Meadowbrook Golf Course and Texas Tech University, respectively. Treatments were applied using a $\mathrm{CO}_{2}$ pressurized backpack sprayer equipped with XR8004VS Teejet (Teejet flat-fan extended range spray tips; Spraying Systems Co., Wheaton, IL) nozzle tips calibrated to deliver $374 \mathrm{~L} \cdot \mathrm{ha}^{-1}$ at $221 \mathrm{kPa}$.

Percent bermudagrass phytotoxicity and percent dallisgrass control were estimated visually. Bermudagrass phytotoxicity was rated at 2 and 4 WAIT, on a scale of $0 \%$ (no visible phytotoxic symptoms) to $100 \%$ (complete turfgrass necrosis). Dallisgrass control was rated at 10 and 37 WAIT on a scale of $0 \%$ (no dallisgrass control) to $100 \%$ (complete dallisgrass removal). No significant location interactions were detected, thus data were combined. Data were analyzed using analysis of variance (ANOVA) and means were separated using Fisher's protected least significant difference test $(\alpha=$ 0.05 ) provided by SAS (Release 9.2; Statistical Analysis Systems Institute, Cary, NC). All TFH treatments were subsequently analyzed by a separate ANOVA and orthogonal contrasts were performed to analyze the relationship of application timing, rate, and application number on dallisgrass control with this herbicide (Table 2).

\section{Results and Discussion}

Bermudagrass toxicity. No bermudagrass phytotoxicity was detected in response to any treatment at any rating date (data not shown). Similarly, Henry et al. (2013) reported $<3 \%$ bermudagrass phytotoxicity within $7 \mathrm{~d}$ of early summer applications of TFH at $22+$ $45+70 \mathrm{~g}$ a.i./ha as well as TID at $30+7+$ $197 \mathrm{~g}$ a.i./ha. Cross et al. (2011) noted 0\% bermudagrass injury from fall foramsulfuron + TID applications. Busey (2004) noted only $3 \%$ to $7 \%$ bermudagrass phytotoxicity within 5 weeks of foramsulfuron applications at 29 to $44 \mathrm{~g}$ a.i./ha. Results of this research align with previous reports that these herbicides are likely safe to use on bermudagrass both early and late in the growing season.

Dallisgrass control. Dallisgrass control 10 WAIT was $\leq 35 \%$ with all single applications of TFH (Table 1). Control from sequential applications of foramsulfuron at $106 \mathrm{~g}$ a.i./ha was $35 \%$. Similarly, Henry et al. (2007b) reported $19 \%$ to $40 \%$ dallisgrass control 3 MAIT in response to sequential foramsulfuron treatments applied in early June. In contrast, Breeden and McElroy

Table 1. Dallisgrass control in bermudagrass following herbicide applications in field experiments, 2010-12, Lubbock, TX.

\begin{tabular}{|c|c|c|c|c|}
\hline \multirow{2}{*}{$\begin{array}{l}\text { Timing of initial } \\
\text { application }^{z}\end{array}$} & \multirow[b]{2}{*}{ Treatment } & \multirow[b]{2}{*}{ Rate (g a.i./ha) } & \multicolumn{2}{|c|}{ Dallisgrass control (\%) } \\
\hline & & & $10(\mathrm{WAIT})^{\mathrm{y}}$ & 37 (WAIT) \\
\hline September & $\mathrm{TFH}^{\mathrm{x}}$ & $15+31+47$ & 28 & 82 \\
\hline October & TFH & $15+31+47$ & 29 & 39 \\
\hline September & TFH $\mathrm{fb}^{\mathrm{w}}$ TFH 4WAIT & $15+31+47$ & 49 & 92 \\
\hline September & TFH & $22+45+70$ & 35 & 94 \\
\hline October & TFH & $22+45+70$ & 33 & 55 \\
\hline September & TFH fb TFH 4WAIT & $22+45+70$ & 65 & 97 \\
\hline September & Foram $^{\mathrm{v}} \mathrm{fb}$ foram $4 \mathrm{WAIT}$ & 106 & 35 & 48 \\
\hline \multirow[t]{3}{*}{ September } & Foram + TID $^{\mathrm{u}} \mathrm{fb}$ foram + TID & $106+22+5+147$ & 63 & 93 \\
\hline & Nontreated & & 0 & 0 \\
\hline & Least significant difference $(0.05)$ & & 7 & 6 \\
\hline
\end{tabular}

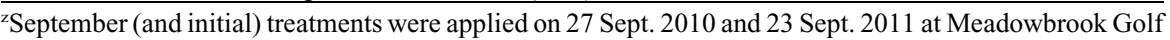
Course and Texas Tech University, Lubbock, TX, respectively. October (and sequential) treatments were applied on 21 Oct. 2010 and 2011 at Meadowbrook Golf Course and Texas Tech University, Lubbock, TX, respectively.

${ }^{\mathrm{y}} \mathrm{WAIT}=$ week after initial treatment.

${ }^{\mathrm{x}} \mathrm{TFH}=$ thiencarbazone-methyl + foramsulfuron + halosulfuron-methyl. All thiencarbazone-methyl + foramsulfuron + halosulfuron-methyl treatments included methylated seed oil and ammonium sulfate at $0.5 \% \mathrm{v} / \mathrm{v}$ and $2 \% \mathrm{w} / \mathrm{v}$, respectively.

${ }^{\mathrm{w}} \mathrm{fb}=$ followed by. Treatments containing sequential applications were made at the same rate as the initial application.

${ }^{\mathrm{v}}$ Foram $=$ foramsulfuron

"TID = thiencarbazone-methyl + iodosulfuron-methyl-sodium + dicamba.

Table 2. Effect of application timing, application rate, and the addition of a sequential treatment of $\mathrm{TFH}^{\mathrm{z}}$ on dallisgrass control in field experiments, 2010-12, Lubbock, TX

\begin{tabular}{llcc}
\hline \multirow{2}{*}{ Treatment } & & \multicolumn{2}{c}{ Dallisgrass control $(\%)$} \\
\cline { 3 - 4 } Single application & September & 10 (WAIT) & 37 (WAIT) \\
& October & 32 & 88 \\
\multirow{2}{*}{ Rate (g a.i./ha) } & Contrast & 31 & 47 \\
& $15+31+47$ & NS & 71 \\
No. of applications & $22+45+70$ & 35 & 82 \\
& Contrast & 44 & $* * *$ \\
& Single (September) & 32 & 88 \\
& Sequential (September + October) & 57 & $* 5$ \\
& Contrast & $* * *$ & $*$
\end{tabular}

${ }^{\mathrm{z}} \mathrm{TFH}=$ thiencarbazone-methyl + foramsulfuron + halosulfuron-methyl

${ }^{\mathrm{y}} \mathrm{WAIT}=$ week after initial treatment.

ns, *, **, *** Nonsignificant or significant at $P \leq 0.05,0.01$, or 0.001 , respectively. 
(2008) noted that sequential spot applications of foramsulfuron in the fall at a high spray volume resulted in $\geq 98 \%$ dallisgrass control 4 weeks after sequential treatment.

Sequential applications of TFH provided $49 \%$ and $65 \%$ dallisgrass control 10 WAIT when applied at $15+31+47$ and $22+45+$ $70 \mathrm{~g}$ a.i./ha, respectively. The sequential foramsulfuron + TID treatment at $106+22+$ $5+147 \mathrm{~g}$ a.i./ha provided $63 \%$ dallisgrass control 10 WAIT and was comparable to control observed with sequential applications of TFH. Cross et al. (2011) reported similar dallisgrass control $(57 \%)$ in response to fall spot treatments of foramsulfuron + TID. Willis et al. (2009) noted that sequential applications of thiencarbazone-methyl at $32 \mathrm{~g}$ a.i./ha in combination with foramsulfuron provided $74 \%$ dallisgrass control 8 weeks after treatment.

By 37 WAIT, sequential applications of TFH provided $92 \%$ and $97 \%$ dallisgrass control when applied at $15+31+47$ and $22+45+$ $70 \mathrm{~g}$ a.i./ha, respectively. Control in response to the $22+45+70 \mathrm{~g}$ a.i./ha rate applied sequentially was the highest level of control observed at any rating date from any treatment. The single application of TFH at $22+$ $45+70 \mathrm{~g}$ a.i./ha in September provided a similar level of control $(94 \%)$. While the single September application of TFH at $15+31+$ $47 \mathrm{~g}$ a.i./ha provided $82 \%$ control, single October applications at both rates resulted in poor control (39\% to 55\%) 37 WAIT. These results may be due to reduced basipetal carbohydrate movement at the time of the October treatment. Weak control (48\%) was also observed with sequential foramsulfuron treatments at $106 \mathrm{~g}$ a.i./ha. On the contrary, Breeden and McElroy (2008), observed $\geq 83 \%$ dallisgrass control 36 weeks after sequential spot applications of foramsulfuron applied in the fall at a spray volume of 200 gallons/acre. The foramsulfuron + TID treatment resulted in $93 \%$ dallisgrass control 37 WAIT, which was almost twice as much as the control offered by foramsulfuron alone and was comparable to the aforementioned TFH treatments.

Effect of application timing, rate, and sequential applications on dallisgrass control from TFH applications. At 10 WAIT, no significant difference in dallisgrass control was detected between single treatments of TFH applied in September or October (Table 2). However, the effect of rate was highly significant $(P \leq 0.001) 10$ WAIT, regardless of the fact that both rates provided poor control $(\leq 44 \%)$. Adding a sequential application in October resulted in control of $57 \%$ whereas a single application in September resulted in only $32 \%$ control at 10 WAIT. Although highly significant, the addition of a sequential application only resulted in 55\% control 10 WAIT.

When pooled across rates, single September applications of TFH resulted in $88 \%$ control 37 WAIT, nearly doubling the control observed with single October applications
(47\%) $(P \leq 0.001)$. When pooled across single application timings, increasing rates of TFH from $15+31+47$ to $22+45+$ $70 \mathrm{~g}$ a.i./ha resulted in improved dallisgrass control from $71 \%$ to $82 \%$, respectively, 37 WAIT $(P \leq 0.001)$. Pooled across rates, the addition of a sequential application resulted in 95\% dallisgrass control 37 WAIT, an increase from the $88 \%$ control observed with single September applications $(P \leq 0.05)$.

Overall, excellent long-term control $(\geq 92 \%)$ was observed in response to several treatments the summer following application. Sequential treatments of TFH were necessary to achieve excellent dallisgrass control (92\%) when applications were made at the low rate $(15+31+47 \mathrm{~g}$ a.i./ha). However, at the high rate $(22+45+70 \mathrm{~g}$ a.i./ha), dallisgrass control in response to TFH applied once in September was similar to the control with sequential applications. This is of great practical value to turf managers that may lack the ability to afford sequential applications. Waiting until October to apply TFH at either rate resulted in poor long-term control. Dallisgrass plants may have initiated dormancy in mid-October, which reduced herbicidal absorption and translocation to rhizome tissue. Sequential applications of foramsulfuron + TID resulted in similar long-term control as sequential treatments of TFH and single treatments at the high rate. Effective fall herbicide timings for dallisgrass control may be environmentally dependent; changing both spatially and temporally. Future research with TFH applications for dallisgrass control should incorporate the accumulation of cooling degree days similar to Elmore et al. (2013) to further increase herbicide efficiency and long-term control.

\section{Literature Cited}

Anonymous. 2016. Tribute ${ }^{T M}$ total herbicide product label. Bayer CropScience LP, Bayer Environment Science Publication, Triangle Park, NC.

Bingham, S.W., W.J. Chism, and P.L. Hipkins. 1993. Postemergence control of johnsongrass, dallis grass, and purpletop in tall fescue. Transp. Res. Rec. 1409:92-94.

Breeden, G.K. and J.S. McElroy. 2008. Alternative timings of ALS herbicides and glyphosate for dallisgrass (Paspalum dilatatum) control. Proc. South. Weed Sci. Soc. 61:123.

Brosnan, J.T., G.K. Breeden, M.T. Elmore, and J.M. Zidek. 2010. Early and late postemergence control of dallisgrass in tall fescue. Appl. Turf Sci. 7(1). doi: 10.1094/ATS-20100312- 02-R.

Bryson, C.T. and G.D. Wills. 1985. Susceptibility of bermudagrass (Cynodon dactylon) biotypes to several herbicides. Weed Sci. 33:848-852.

Busey, P. 2004. Goosegrass (Eleusine indica) control with foramsulfuron in bermudagrass (Cynodon spp.) turf. Weed Technol. 18:634-640.

Cross, R., A. Estes, and B. McCarty. 2011. Postemergence dallisgrass control without MSMA. Proc. South. Weed Sci. Soc. 64:82.

Davis, H.E., R.S. Fawcett, and R.G. Harvey. 1978. Effect of fall frost on the activity of glyphosate on alfalfa (Medicago sativa) and quackgrass (Agropyron repens). Weed Sci. 26:41-45.
Elmore, M.T., J.T. Brosnan, T.C. Mueller, B.J. Horvath, D.A. Kopsell, and G.K. Breeden. 2013. Seasonal application timings affect dallisgrass (Paspalum dilatatum) control in tall fescue. Weed Technol. 27:557-564.

Henry, G., J. Burton, R. Richardson, and F. Yelverton. 2008. Absorption and translocation of foramsulfuron in dallisgrass (Paspalum dilatatum) following preapplication of MSMA. Weed Sci. 56:785-788.

Henry, G.M., M.G. Burton, and F.H. Yelverton. 2007a. Effect of mowing on lateral spread and rhizome growth of troublesome Paspalum species. Weed Sci. 55:486-490.

Henry, G.M., M.G. Burton, and F.H. Yelverton. 2009. Heterogeneous distribution of weedy Paspalum species and edaphic variables in turfgrass. HortScience 44:447-451.

Henry, G.M., C.M. Straw, L.L. Beck, T. Cooper, J.T. Brosnan, and G.K. Breeden. 2013. Nutsedge (Cyperus spp.) control and perennial ryegrass overseeding tolerance to SP25052. Intl. Turfgrass Soc. Res. J. 12:695-700.

Henry, G.M., F.H. Yelverton, and M.G. Burton. 2007b. Dallisgrass (Paspalum dilatatum) control with foramsulfuron in bermudagrass turf. Weed Technol. 21:759-762.

Johnson, B.J. 1992. Common bermudagrass (Cynodon dactylon) suppression in Zoysia spp. with herbicides. Weed Technol. 6:813-819.

Loreti, J. and M. Oesterheld. 1996. Intraspecific variation in the resistance to flooding and drought in populations of Paspalum dilatatum from different topographic positions. Oecologia 108:279-284.

McCarty, L.B., L.C. Miller, and D.L. Colvin. 1991. Bermudagrass (Cynodon spp.) cultivar response to diclofop, MSMA and metribuzin. Weed Technol. 5:27-32.

McElroy, J.S. and G.K. Breeden. 2006. Triclopyr safens the use of fluazifop and fenoxaprop on zoysiagrass while maintaining bermudagrass suppression. Appl. Turf Sci. 3(1). doi: 10.1094/ATS-2006-0502-01-RS.

Rubio, G., G. Casasola, and R.S. Lavado. 1995. Adaptations and biomass production of two grasses in response to waterlogging and soil nutrient enrichment. Oecologia 102:102-105.

Rubio, G. and R.S. Lavado. 1999. Acquisition and allocation of resources in two waterloggingtolerant grasses. New Phytol. 143:539-546.

Smith, B.E., D.G. Shilling, W.T. Haller, and G.E. Macdonald. 1993. Factors influencing the efficacy of glyphosate on torpedograss (Panicum repens L.). J. Aquat. Plant Manage. 31:199-202.

United States Environmental Protection Agency. 2009. Agreement in principle to implement the organic arsenicals Reregistration Eligibility Decision (RED). U.S. Environmental Protection Agency, Washington, DC. 24 Aug. 2015. $<$ http://www.regulations.gov/\#documentDetail; D=EPA-HQ-OPP-2009-0191-0004>.

United States Environmental Protection Agency. 2015. Monosodium methanearsonate (MSMA), an organic arsenical. U.S. Environmental Protection Agency, Washington, DC. 24 Aug. 2015. $<$ http://www2.epa.gov/ingredients-used-pesticideproducts/monosodium-methanearsonate-msmaorganic-arsenical $>$.

Willis, J.B., M.J. Goddard, J. Keating, and S.D. Askew. 2009. Evaluation of selected herbicides for dallisgrass control. Proc. South. Weed Sci. Soc. 62:84.

Wills, G.D. 1987. Description of purple and yellow nutsedge (Cyperus rotundus and C. esculentus). Weed Technol. 1:2-9. 